\title{
RAPORTUL DINTRE RELIGIE ȘI MORALĂ ÎN ECUAȚIA PAIDEICĂ A EDUCAȚIEI TINERETULUI CONTEMPORAN
}

\author{
Oliviu-Petru Botoi*
}

\begin{abstract}
For any society, religion and morality represented the most important elements that have provided a spiritual outline and a metaphysical dimension designed for the concrete aspects of daily life.Every religion proposes a moral that religious man assumes and attempts to achieve in its entirety. Along with the development of society through the emergence of the political ideologies and the civil law, were regulated by law some universally recognized and indispensable aspects of morality, afterwards undertaken through education and fined by the political authority. In post-modern society, education holds a central place in the becoming of a nation. Beyond the professional training and the minimal imposed deontological ethics, education is deprived of the paideia training of the individual spirit. Religion, as a study discipline that could compensate this lack of moral and spiritual, is subject to certain attacks which aim it's exclusion from school curricula. Detrimentally, it is believed that religion, in its complexity, must be replaced by secular morality, autonomous in relation to religion. The moral purpose is not only to discipline the society, but helping people to perfect and deontological fulfill.
\end{abstract}

Keywords: education, humanism, post-modernity, person.

\section{Introducere}

Noile tendințe postmoderne, într-o încercare tendențioasă de a propune un nou concept și o nouă formă de spiritualizare a omului și a lumii, promovează și accentuează o autonomizare forțată a religiei și a moralei. Deși, până la un anumit punct, un asemenea demers are rațiuni verosimile și ideea unei critici obstrucționiste nu se susţine prin argumente pertinente şi nici nu se justifică întotdeauna, totuşi este indispensabilă defensiva firescului prin care se relevă o relație de complementaritate și cauzalitate între cele două

* PhD candidate, Faculty of Orthodox Teology, „1 Decembrie 1918” University, Alba Iulia, Romania. 
elemente, anume religia și morala. Despărțirea religiei de morală ar putea fi socotită drept o acțiune fără sens, însă totuși aspectul nu poate fi neglijat, din motivul întemeiat că morala nu poate deveni un simplu cod etic bazat pe principiile așa numitului „bun simț” sau pe legea naturală, care, oricum, are nevoie de perfectare, ci trebuie să propună „rețete” duhovnicești prin care se diminuează impulsul vicios al slăbiciunii omenești. În sens invers, nici religia nu poate fi transformată într-o filosofie gnoseologică, adaptată unor situații și vremuri sau personalizată în funcție de capacitatea de înțelegere a oamenilor.

Devenirii persoanei umane, în complexitatea ei, îi este indispensabilă asumarea moralei naturale și desăvârșirea $\mathrm{ei}^{1}$. Procesul înțelegerii și asumării moralei naturale în complexitatea dimensiunii ei creștine conduce negreșit la împlinirea umanului atât ca țintă a vieții duhovnicești, cât și ca nevoie ontologică a omului ${ }^{2}$. Însă, atunci când vorbim despre nevoia ontologică a omului, căutătorul veșnic, care își îndreaptă propriile acțiuni după rațiuni personale și, evident, în scop personal, trebuie să avem în vedere și legitimarea logicii lui într-un sistem care îl leagă de supranatural. „Legea naturală” poate fi oricând înăbușită și suprimată prin rațiuni extrinseci pe care omul și le asumă drept căi spre împlinirea lui spirituală. În acest sens, sunt cât se poate de firești căutarea unor răspunsuri care ne dumiresc asupra unor întrebări precum: cât de autonomă poate fi morala naturală? În ce își are temeiul morala și cum se legitimează aceasta în fața unei nevoi a ființei? Morala poate deveni autonomă, încât să nu mai putem vorbi despre o morală a religiei, ci mai degrabă despre o religie a moralei care își cere drepturile la universalitate?

Dincolo de aparențele unei retorici dialectice și sofiste stă o realitate a zilelor noastre care este destul de nelămurită. Educația în devenirea și evoluția unui popor constituie o preocupare constantă pentru bunul mers al societăţii. În esența ei, educaţia este un fenomen

$1 \dagger$ Irineu Pop, Cu Hristos pe calea vieții, Cluj-Napoca, Edit. Presa Universitară Clujeană, 2006, pp. 52-55.

${ }^{2}$ Nichifor Crainic, Sfințenia - implinirea umanului, Iași, Edit. Trinitas, 1993, 
complex și greu de teoretizat, mai ales atunci când vine vorba despre natura omului și nu despre obiceiurile lui, care într-adevăr, pot deveni o ,a doua natură" a acestuia. Și atunci când vine vorba despre educație, omul nu se poate socoti un element saturat, ci se află într-o continuă perfecționare a spiritului. Deși, atunci când se vorbește despre educație ar trebui să avem în vedere toate formele care o alcătuiesc și îndelungatul proces la care omul este supus prin aceasta, însă, educația s-a îndreptat într-un domeniu mai specific, preocupându-se in mod deosebit de copii și tineri. Așa după cum spunea și Axel Oxenstierna, anume că „Buna creştere a tineretului este garanţia cea mai sigură a fericirii unui stat"”, educaţia trebuie să treacă, desigur, dincolo de limitele unei pregătiri profesionale sau deontologii profesionale și să fie îndreptată spre perfectarea personalității umane spre împlinirea personală și spre responsabilitate socială altruistă.

\section{Religia -desăvârșirea morală a spiritului}

În termeni generici, religia ar putea părea destul de ușor de definit, însă, aproape orice definiție, mărginește înțelesul complex al termenului. Conceptul a căpătat un uz general, scăpat de ispita confesionalizării, astfel încât, subliniază în esență raportul omului cu divinitatea prin evidențierea conturului comunitar al expresiei credinței. Chiar dacă termenul are proprietatea semantică a neutralității, el este asumat de către majoritatea credințelor lumii ca o expresie epidermică sub care se ascunde un conținut teoretic și practic care oferă adevărata dimensiune şi culoare a religiei. Simplul apel la un dicționar de uz general, ne scoate la iveală următoarele aspecte, în ceea ce privește religia, prin care aceasta este definită drept ,ansamblu de credințe, dogme și practici care definesc raportul dintre om și divinitate” sau „credință în ființe sau forțe supranaturale (Dumnezeu, zei, sfinți, îngeri, duhuri, demoni etc.) manifestată prin oficierea unui cult și prin existența unor organizații și instituții

3 Teofil Tia, Pedagogia pastorală şi criza valorilor, Alba Iulia, Edit. Reîntregirea, 2004, p. 2. 
corespunzătoare" ${ }^{4}$.Sub aceeași idee prezintă semantica cuvântului religie și dicționarele limbilor moderne,accentuând dimensiunea declarată și cultuală a unei credințe într-unul sau mai mulți zei ${ }^{5}$.

În esență, însuşi termenul religie presupune mai mult decât ceea ce pot exprima dicționarele de masă sau decât ceea ce se cunoaște în mod general de către majoritate. Pornind de la geneza conceptului, în linii cunoscute, se vorbeşte despre două posibile etimologii ${ }^{6}$ ale cuvântului religie. Există şi o a treia ipoteză foarte puţin cunoscută şi rar împărtăşită în lumea specialiştilor. Prima dintre acestea i se atribuie scriitorului creştin Lactanţiu, care susţine părerea gramaticianului roman Maurus Servius Honoratus asupra originii acestui cuvânt: „Relligio, id est metus ab eo quod mentem religet, dicta religio"'. Lactanţiu îl citează şi pe poetul Lucreţiu, care în lucrarea De Rerum Natura nota,religionum animum nodis exsolvere

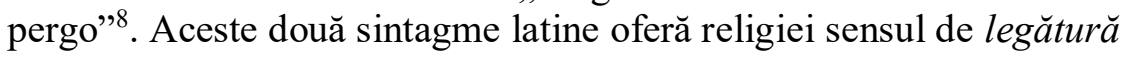

4 *** Dicționarul explicativ ilustrat al limbii române, s.l., Edit. Arc-Gunivas, 2007, p. 1659. Sau, de asemenea ,ansamblu de idei, sentimente și acțiuni impărtășite de un grup și care oferă membrilor săi un obiect de venerare, un cod de comportament, un cadru de referință pentru a intra în relația cu grupul și universul; confesiune, credință" (DEX, 2009); Ansamblu de idei, sentimente și acțiuni împărtășite de un grup și care oferă membrilor săi un obiect de venerare, un cod de comportament, un cadru de referință pentru a intra în relație cu grupul și universul. De obicei, religia distinge între real și supranatural, vizează ceva ce transcende cunoscutul sau naturalul, este o recunoaștere a misteriosului și a supranaturalului; religia include un concept sau o divinitate care implică omul într-o experiență dincolo de nevoile lui personale sau sociale imediate, recunoscută ca ,sacră” sau ,sfântă” (Dicționar enciclopedic).

${ }^{5}$ Pentru a contura ideea principală a definițiilor generale ale religiei în spațiul european, vezi *** Oxford Dictionary, Oxford-New York, Oxford University Press, p. 1231; *** Dictionary for Contemporary English, PrsonLongman, 2009, p. 1471; *** Dictionnaire Larousse, Paris, Larousse, 2011, p. 1191; *** LoZingarelli Minore, Bologna, Zanichelli, 1998, p. 809.

6 Emil Jurcan, Lumea religioasă veche. Mesaje antice despre revelaţia pierdută, Alba Iulia, Edit. Reîntregirea, 2003, p. 11.

7 Sarah F. Hoyt, The etimology of Religion, în „Journal of the American Oriental Society", vol. 32, nr. 2. 1912, p. 126.

${ }^{8}$ Titus Lucretius Carus, De Rerum Natura, I, 932 (text consultat la adresa web http://www.thelatinlibrary.com). 
sau re-legătură. Teologic vorbind ar trebui să fie vorba despre legătura omului cu Dumnezeu, legătură care a fost întreruptă într-un anumit moment al istoriei religiei (în religiile monoteiste odată cu greşeala strămoşului Adam), şi care trebuie restabilită. Or, restabilirea acestei legături dintre om şi Dumnezeu ar însuma scopul religiei. Altă ipoteză, puţin cunoscută şi rar împărtăşită, are în vedere sensul de obligaţie, având în vedere rădăcina latină lig, care a generat de asemenea şi alte cuvinte latine, cum ar fi licton sau lex 9 . Cicero, deşi a afirmat ipoteza lui Lucreţiu, în lucrarea De Natura Deorum afirmă etimologia cuvântului religie de la relegere, adică amerge prin sau din nou prin citire, vorbire şi gândire ${ }^{10}$ : „Qui omnia quae ad cultum deorump ertinerentd iligenterp ertractarente, tamquamr elegerent, sunt dicti religiosi ex relegendo, ut elegantes ex eligendo" 11 .

Încercarea de a descrie un raport dintre religie și morală, reflectat în modul de implementare a educaţiei în zilele noastre, trebuie să aibă în vedere cel puțin încă două componente de bază, anume știința și filosofia etică. Ultimele două, în opinia unor specialiști, doresc să se suprapună peste ceea ce oferă religia și morala ei. Deși problematica a fost supusă unor ample analize încă din secolul trecut ${ }^{12}$, totuși realitatea existenței nu poate adera deloc în favoarea acestei schimbări ${ }^{13}$. Religia și morala rămân în continuare ceea ce au fost dintotdeauna, iar știința și filosofia etică continuă demersul de înnoire permanentă în funcție de spiritul veacului și de noile descoperiri de ordin științific sau de noile provocări ideologice la care este supus omul contemporan. Încă din timpul Renaşteri au existat multe predicții, care în cele din urmă s-au dovedit false ${ }^{14}$ și

\footnotetext{
${ }^{9}$ Sarah F. Hoyt, art. cit., p. 126.

${ }^{10}$ Ibidem, p. 127.

${ }^{11}$ Ibidem.

${ }^{12}$ Lev Tolstoi, Religia și morala pot fi înlocuite prin filosofie și științăa?, s.n., Mănăstirea Neamțu, 1856.

${ }^{13}$ Vezi Henri Bergson, Cele două sensuri ale religiei și moralei, Traducere și studiu introductiv de Diana Morărașu, Iași, Edit. Institutul European, 1992.

${ }^{14}$ Friedrich Nietzsche, Karl Marx, Signund Freud, J. Frazer, L. Feuerbach, B. Russel et alii.
} 
fără temei, despre sfârşitul iminent al religiei ${ }^{15}$. Însă, în pofida unor asemenea predicții prin care se enunța răspicat anihilarea religiei, secolul XXI a intensificat preocupările pentru sfera religioasă, conturându-se o tendință spre religiozitatea de orice fel.

După cum arătam în cele prezentate mai sus, religia nu poate fi socotită, nici pe departe, numai un ansamblu al unor expresii ale spiritului dintr-un anumit moment istoric sau dintr-un anume loc, ci călăuzește omul spre o regăsire a sinelui în raport cu Dumnezeu (religare), supunându-l unui exercițiu noetic de (re)descoperire a lui Dumnezeu. În pofida părerilor care consideră religia o iluzie efemeră sau o himeră ${ }^{16}$ care a marcat conștiința oamenilor până într-un anumit moment al istoriei, se dovedește din ce în ce mai limpede faptul că religia aduce numeroase beneficii, atât de ordin fizic, cât și spiritual, pentru om. „Tot mai mulți analiști avizați subliniază că, în realitate, tenacitatea remarcabilă a religiei îşi are rădăcinile în ceva mult mai profund, cu mult mai simplu și mai sănătos decât o renegare veleitară sau decât o pură dependență psihologică. Oamenii de știință arată co originile religiei sunt cu mult mai complexe și că ele se fondează pe experiența mistică, că religiile persistă întrucât conexiunile creierului uman continuă să furnizeze credincioșilor o serie de experiențe unitare, interpretate deseori ca argumente că Dumnezeu există"17.

Postmodernitatea târzie anunţă şi o altă realitate care de această dată nu neglijează şi schimbă orientarea religioasă a omului european, ci îşi propune din capul locului şă distrugă până la origini sentimentul religios. Ținta umanismului secular implică şi atrage după sine numeroase acţiuni împotriva religiei, a clerului şi a Bisericii în general. Deşi de cele mai multe ori umanismul ne este recomandat ca nefiind altceva decât ateism, totuşi el tinde mai mult

\footnotetext{
${ }^{15}$ Lucian Blaga, Curs de filosofia religiei, Alba Iulia-Paris, Edit. Fronde, 1994, p. 190.

${ }^{16}$ Vezi Richard Dawkins, Himera credinței în Dumnezeu, Ed. a II-a, București, Edit. Curtea Veche, 2012.

${ }^{17}$ Nicolae Achimescu, Religia, benefică nu doar pentru suflet, ci și pentru trup, în vol. „Religie, modernitate și postmodernitate”, col. Media Christiana, București, Edit. Trinitas a Patriarhiei Române, 2013, p. 132.
} 
spre un antropocentrism, prin care Dumnezeu este înlocuit de valoarea şi inteligenţa umană. Spaţiul doctrinar al religiozităţii fiinţiale omului ${ }^{18}$ este umplut cu încrederea egoistă în puterea raţiunii şi progresului social.

Unul dintre cei mai reprezentativi teologi și duhovnici ai secolului al XX-lea, care nu a fost străin deloc de duhul european din secolul în care a trăit a descris foarte subtil această autonomizare a antropologicului în fața Divinității de care este „dependent." „Evoluţia ulterioară a Umanismului avea să se lege cu o crescândă rupere de Dumnezeu şi cu cultul omului: totul era în funcţie de om, el fiind cea mai înaltă valoare în viaţa cosmică. Nu este greu a discerne în această mişcare a «renaşterii», căderea cea din Rai, cu o înnoită putere, în istoria omenirii. Tot umanismul, în vârtutea parţialei şi mai deplinei îndepărtări de Dumnezeu, înjoseşte nivelul omului şi el devine «produsul naturii», supusul stihiilor cosmosului făcut şi, în acelaşi timp, al ideilor lui abstracte" ${ }^{\prime 19}$.

Pornind de la trăsăturile Umanismului renascentist care nu se exprima ca o revoltă împotriva religiei, ci mai degrabă ca o ieşire de sub imperiul exagerat al normei, caracteristicile atitudiniisecularumaniste sunt: suspiciune față de orice ierarhie obiectivăa valorilor, nevoia de a șterge relația unuia cu mediul obiectiv al altcuiva prin acțiunea autonomă a conștiinței de sine, de asemenea, puterea cuvântului rostit ca atare, încrederea în efectele vorbirii între om și om - toate acestea, și nu o ontologie specifică a adevărului.Cu toate acestea, se desprinde de asemenea o nouă atitudine faţă de istorie: istoria devine suma totală a diferitelor forme ale experienței umane. Este în judecarea acestor forme (și nu în judecarea evenimentelor

18 Christos Yannaras, Contra religiei, Traducere din limba greacă de Tudor Dinu, Prefaţă de Sorin Dumitrescu, Bucureşti, Edit. Fundaţiei Anastasia, 2011. (Oricât ar fi progresat în cultivarea intelectuală, în gândirea critică ori cunoaşterea ştiinţifică, pentru viaţa sa omul va recurge în mod instinctual în faţa unei primejdii la un protector supranatural; p. 14).

${ }_{19}$ Arhimandritul Sofronie, Naşterea întru Impărăţia cea neclătită, Traducere din limba rusă de Ierom. Rafail (Noica), Tipărită cu binecuvântarea Înalt Preasfinţitului Andrei Arhiepiscop al Alba Iuliei, Alba Iulia, Edit. Reîntregirea, 2003, p. 135. 
istorice, deși studiul lor nu este deloc neglijat), că o noțiune nouă a umanității este concepută, gândirea istorică este formată și problema de decizie morală este dezvoltată ${ }^{20}$.

Noua ordine socio-religioasă pe care umaniştii urmăresc să o desăvârşească începe să prindă contur. După secole în care s-a secularizat simţitor relaţia dintre Stat şi Biserică, se încearcă încă şi mai mult. S-a încetăţenit un model comun al religiei în Europa ${ }^{21}$ care încă mai face faţă pentru o vreme presiunilor umaniste, anume: „Statul este neutru faţă de varietatea de subiecte individuale de ordin religios; un sub-sector religios iese în evidenţă în cadrul sectorului public. Acesta are înţelesul de arie protejată şi, în interiorul său, subiecte colective de ordin religios sunt libere să acţioneze în contextul existenţei unor avantaje substanţiale, prin comparaţie cu acele subiecte colective care nu au o natură religioasă. Statul are dreptul să intervină în acest domeniu religios doar pentru a vedea dacă judecătorii respectă regulile jocului şi nu ies în afara limitelor terenului de joc"22.

Percepția omului asupra religiei și preocupările constante pentru diseminarea științifică a conceptului sunt într-o continuă și alertă schimbare. În ultima vreme, se vorbește mai mult de un tip de religie post-secularistă ${ }^{23}$, marcată în continuare de un antropocentrism, îndreptat de această dată spre antropologia religioasă din cele mai exotice tradiții culturale. De asemenea,

\footnotetext{
${ }^{20}$ Richard Hoenigswald, On Humanism, în „Philosophy and Phenomenological Research", vol. 9, No. 1, Sep. 1948, p. 43 cf. (http://www.jstor.org/stable/2103850).

${ }^{21}$ Silvio Ferrari, The New Wineandthe Old Cask: Tolerance, Religion, andthe Law in Contemporary Europe, în Andras Sajo, Shlomo Avineri, „The Law of Religious Identity: Models for Post-Communism”, KluWer, The Hague, 1999, pp. 2-3.

${ }^{22}$ Radu Carp, Stat, Biserică, cetăţean - în căutarea unui model european al religiilor, în Teodor Baconsky, Ioan I. Ică jr., Bogdan Tătaru-Cazaban, Pentru un creştinism al noii Europe, Bucureşti, Edit. Humanitas, 2007, p. 294.

${ }^{23}$ Nicolae Achimescu, Secularism versus identitate religioasă, în vol. „Religie, modernitate ...", pp. 214-216.
} 
tendinţele de tip scientologist ${ }^{24}$ sau gnosticist se autopropun drept forme pseudo-religioase impuse drept surogate ale unei identități religioase asumate. Chiar și formele declarate prin care religia este asumată pot fi noi formule care denaturează sensul originar al religiei.,Din perspectivă religioasă, se constată azi, mai mult ca oricând, o tendinţă spre ,privatizare“ sau subiectivare. Odată privatizată şi subiectivată, religia nu mai are decât un impact minor asupra societăţii" 25 .

\section{Morala - consecința asumării religiei}

În ciuda respingerii religiei ca fenomen comunitar, societatea contemporană a devenit extrem de atentă și sensibilă la asumarea și protejarea moralei, tradusă în coduri etice drept produse ale minții umane trecute prin experiența istoriei. Chiar dacă existența lui Dumnezeu nu poate fi rezumată la necesitatea morală prin care cea mai de pe urmă și-ar legitima ca lege transcendentală, totuși rațiunile lui Immanuel Kant, secondat de Sorley, Trueblood sau C.S. Lewis ${ }^{26}$ susțin interdependența raportului dintre religie și morală. Într-o primă fază a exercițiului de diseminare a celor două elemente, am fi tentați să ne aliniem gândirii psihanalitice târzii, prin care am fi justificați să acceptăm autonomizarea moralei față de religie, văzută ca un produs al educației și instruirii persoanei umane în relația sa cu transcendentul.

Ontologic, binele este legat de Dumnezeu, răul este separare de El. „În condițiile noastre este greu de spus dacă o conștiință morală și religioasă s-ar putea dezvolta fără educație. Prezența conștiinței morale se manifestă deja la copil prin rușine, frică, mulțumire, înainte ca un copil să fi fost învățat să gândească despre Dumnezeu. El cunoaşte deja opoziţia dintre bine şi rău. Deci

24 Idem, Civilizația tehnică și religia postsecularistă, în vol. „Religie, modernitate ...", p. 179.

${ }^{25}$ Idem, Pericolul privatizării religiei, în vol. „Religie, modernitate ...”, p. 297. ${ }^{26}$ Norman L. Geisler, Filosofia religiei, Oradea, Edit. Cartea creștină, 1999, pp. 129-133. 
elementul originar al cunoașterii conștiinței este moral și nu religios" ${ }^{27}$. Acest lucru ar putea rămâne universal valabil numai dacă nu se trece dincolo de constatările antropologice și fără să examinăm atent antropologia legată ontologic de ideea de divinitate. Faptul că omul din fire este o ființă morală este cât se poate de adevărat și argumentat din punct de vedere biblic și patristic. Însă, ,,învățătura creștină explică această natură morală a omului, această dispoziție firească a lui de a face binele, prin faptul că a fost creat de Dumnezeu astfel, încât din fire să poată face nu numai deosebirea dintre bine și rău, dar totodată să știe că binele trebuie făcut, iar răul trebuie evitat" ${ }^{28}$.Dacă El există sau nu, de «credem în El» sau nu erau chestiuni superflue. Fără ideea de Dumnezeu nu există sens, adevăr sau morală absolută, iar eticadevine doar o chestiune de gust, o stare de spirit sau un capriciu. Dacă nu reușesc să includă ideea de «Dumnezeu», politica și morala vor rămâne pragmatice și viclene, nu înțelepte. Iar, dacă nu există absolut, atunci nu avem motive să nu urâm, și războiul nu este mai rău decât pacea. Religia este, prin excelenţă, un sentiment interior că există Dumnezeu"29.

Flagelul secularismului nu a făcut excepție nici în ceea ce privește sfera moralei. Înțeleasă și receptată ca o necesitate pentru orice tip de societate, morala a început să fie privată de componenta ei religioasă și să se autoproclame independentă, revendicându-și un trecut, un istoric prin care era autonomă față de religie. „Morala secularizată de azi nu e decât rezultatul confuziei dintre bine și râu, ca și a asimilării legalităţii cu moralitatea. În consecinţă, ceea ce este permis de lege devine, pentru cei mai mulți, bun. Dinperspectivă creștină, însă, acest lucru nu este acceptabil, întrucât adevărul nu se decretează prin majoritate" 30 . Moralitatea și viața morală nu pot fi

27 Gheorghe Popa, Introducere în teologia morală. Principii și concepte generale, Iași, Edit. Trinitas, 2003, p. 109.

${ }^{28}$ Nicolae Mladin, Orest Bucevschi, Constantin Pavel, Ioan Zăgrean, Teologia morală ortodoxă, vol. I, Alba Iulia, Edit. Reîntregirea, 2003, p. 16.

${ }^{29}$ Karen Armstrong, Istoria lui Dumnezeu, Traducere din limba engleză de Dana Ionescu, București, Edit. Nemira, 2009, pp. 447-448.

${ }^{30}$ Nicolae Achimescu, Secularizarea moralei, în vol. ,,Religie, modernitate ...”, p. 414 . 
socotite doar simple elemente de disciplinare a societății, ci, mai degrabă, forme prin care persona umană, în ansamblul ei, poate ajunge la desăvârşire. Or, acest lucru nu poate fi legat numai de ochestiune de obișnuință a firii, ci trebuie să aibă rațiuni mult mai adânci, fiind legată de ceea ce ne propune religia: anume desăvârşirea omului, sfințirea umanului. „Fiindcă moralitatea se sprijină pe acceptarea ideii că binele este scopul existenței lumii fiindcă Dumnezeu din propria bunătate a creat-o -, iar acceptarea presupune credință, rezultă, așadar, că moralitatea are un caracter religios, fiindcă cel ce acceptă Binele cel mai presus de simțire, ca scop al existenței lumii în pronia și cârmuirea dumnezeiască" ${ }^{\prime 3}$.

Societatea contemporană a intrat într-un proces al secularizării prin care religia devine o chestiune privată, iar morala doar un simplu

,ansamblul al convingerilor, atitudinilor, deprinderilor reflectate și fixate în principii, norme, reguli, determinate istoric și social, care reglementează comportarea și raporturile indivizilor între ei, precum și dintre aceștia și colectivitate și a căror respectare se întemeiază pe conștiință și pe opinia publică; etică"’32,

devenind astfel un element privat de religie. Această idee îndreptățește oarecum și excluderea religiei din trunchiul comun al programelor de învățământ și înlocuirea ei cu o altă disciplină (etică, istoria religiilor, cultură civică etc.) care să trateze chestiunea fără implicarea fenomenului religios, prin care s-ar ,diminua” oarecum proprietatea responsabilă a actelor morale. Temeiul unui asemenea demers este susținut în parte prin revendicările de ordin științific ale umanismului secular care propune autonomizarea moralei, începând încă din Antichitate, prin folosirea termenului de eticăa. „Este drept că, în timp, sub denumirea de Etică se alcătuiesc discursurile filosofice referitoare la comportamentul ori purtarea umană, încă din

${ }^{31}$ Sfầntul Nectarie de la Eghina, Morala creștină, Traducere din neogreacă de Laura Enache, studiu introductiv de Constantin I. Cornarachi tradus în limba română de Diana Cărburean, Iași, Edit. Doxologia, 2013, p. 116.

${ }^{32}$ Vezi $D E X$ și celelalte ediții de dicționare citate din care reiese aceeași idee. 
Antichitate, Aristotel scriind celebrul său tratat intitulat Etica nicomahica ${ }^{’ 33}$. Însă, Morala lui Aristotel este o moralã a înţelepciunii practice şi nicidecum a conştiinţei sau a responsabilitãţii. Imperativul moralei aristotelice este punerea în aplicare efectivã a virtuţii. Numai virtutea imprimã rectitudine abilitãţii şi o orienteazã pe aceasta spre acceptarea imperativului raţional care este conditia principalã a acţiunii morale. Virtutea presupune efortul omului de a-şi perfecţiona înzestrarea naturalã.

Pentru un răspuns creștin teologic la provocarea umanismului secular în mileniul al treilea, trebuie să stabilim de la început faptul că este nevoie de o împrospătare a apologeticii secolului trecut, care semnala o dramă a umanismului ateu, spre deosebire de situația din zilele noastre în care acel umanism a murit, reconfigurându-se sub o altă formă care deschide un apetit surprinzător pentru omul, și mai ales pentru intelectualul contemporan. Au fost în veacurile trecute teologi de înaltă ținută, dar și filosofi sau scriitori care au criticat atitudinea umanistă și au demonstrat faptul că aceasta avea picioarele de paie. Revendicările pretențioase ale umanismului în istoria lumii sunt doar tentații ale unor corespondențe de formă de care o critică pertinentă trece la prima privire mai atentă asupra temei.

Este de apreciat meritul părintelui Henri de Lubac, care a publicat în anul 1944 celebra carte Drama umanismului ateu ${ }^{34}$, o lucrare care a reușit pe deplin să demonstreze faptul că Feuerbach, Nietzsche și Auguste Comte nu au fost decât niște alcătuitori de filosofii perene, care au trecut odată cu primele schimbări majore de ordin socio-politic. Fidelitatea față de învățătura lui Hristos și înțelegerea profundă a teologiei creștine, așa cum este cazul lui Dostoievsky, au ajuns, mai mult ca sigur fără să-și propună autorul acest lucru, să facă din personalitatea marelui scriitor, un ,profet religios”, a cărui „filosofie” a rămas valabilă şi în zilele noastre

${ }^{33}$ Ionel Ungureanu, Persoană și ethos. Ințelegeri de etică teologică ortodoxă, Iași, Edit. Doxologia, 2013, p. 43.

${ }^{34}$ Henri de Lubac, Drama umanismului ateu, Traducere din limba franceză de Cornelia Dumitru, București, Edit. Humanitas, 2007. 
deoarece este altoită pe trunchiul Scripturii Sfinte şi al experienţei Sfinţilor Părinţi.

Reabilitarea fundamentului creștin al umanismului în general, este fructul unei evoluții care se înrădăcinează în reacția teologiei rusești față de naturalismul naturalist al Occidentului spre sfârșitul secolului trecut. De la Feodor Mihailovici Dostoievsky sau Alexis Khomiacov la Vladimir Soloviov, Paul Evdokimov și Sergiu Bulgakov, toți acești gânditori au oferit Europei o nouă viziune asupra lumii ${ }^{35}$. Unul dintre aceștia, Nicolae Berliaev, a devenit principalul propagator al criticii umaniste, fiind favorizat de lungul său exil și de legăturile familiale cu Franţa. Lecturile sale din Sfântul Grigorie de Nazianz și din Sfântul Grigorie de Nyssa, meditația la dogma calcedoniană care reprezenta divinul și umanul „unite fără amestecare, fără schimbare, nedespărțite" 1-au făcut să descopere sursele spiritualității ortodoxe al cărui scop este deificarea (theosis) omului. Această viziune este în centrul operei sale pe care a publicato în anul 1916: Sensul actului creator: eseu de înțelegerea omului. Se prezintă revelația ca o întâlnire a celor doi poli. Dacă proiectul lui Dumnezeu era să strângă la El toți oamenii, umanitatea suportă o convertire care își transcende propria ontologie. Acest lucru se exprimă prin comuniunea Sfintelor Taine unite în Trupul mistic al lui Hristos. Prin participarea la cercul lui Maritain, pe la începutul anilor douăzeci ai secolului XX, Berliaev va influența gândirea franceză. Este vorba despre ceea ce va purta numele de Noua Renaștere.

În Apusul Europei creștinismul s-a transformat treptat în umanism. Multă vrteme și cu perseverență, occidentalii l-au restrâns pe Dumnezeul-om, iar în cele din urmă l-au micşorat într-un om, în omul infailibil al Romei și în nu mai puțin infailibilul om al Berlinului. În acest fel s-a ivit, pe de o parte, umanismul creștin apusean maximalist care răpește totul lui Hristos și, pe de altă parte, umanismul creștin apusean minimalist (protestantismul), care

\footnotetext{
35 *** Dictionnaireoecumenique de la mission. Cent motspour la mission, Sous la direction de Ion Bria, Philippe Chanson, Jacques Gadile, Marc Spindler, Paris-Geneve-Yaounde, Les Editions du Cerf, Labor et Fides, Leseditions CLE, 2003, p. 148.
} 
aşteaptă de la Hristos tot ce poate fi mai puțin și adesea nimic. În amândouă ca valoare supremă și ca ultim criteriu, în locul Dumnezeului-om este plasat omul. ..S-a săvârșit în felul acesta trista îndreptare (correctio) a Dumnezeului-om, a operei Lui și a învățăturii Lui” ${ }^{36}$.

\section{Concluzii}

Atunci când vorbim despre educaţia tineretului nu se poate scăpa din vedere componenta dezvoltării spirituale și interioare a acestora. De bună seamă că în acest sens intervin mulți factori iar abordarea problematicii presupune multe repere și demersul devine din ce în ce mai dificil. Devenirea persoanei umane nu poate fi determinată numai de o simplă formă de învățământ prin care se aplică metode pedagogice specifice. Aici, trebuei să se aibă în vedere atât educația formală, cât și cea non-formală și informală, Biserica, familia, societatea ș.a.. Însă, cu toate acestea, trebuie să existe o expresie limpede și clară, integrată într-o formă oficială și sistemică, prin care parcursul spiritual și creșterea spirituală a persoanei devine o preocupare pentru evoluția societății și bunul mers al comuntăților sociale. Din tot ceea ce oferă învățământul românesc ${ }^{37}$ și cel european, această chestiune se poate rezuma la ora de religie sau la formele ei prin care ea este prezentată în sistemele educaționale naționale ${ }^{38}$. În România, trecutul foarte recent și prezentul ne pun în fața unei presiuni care dorește o schimbare esențială. Deși, formal

36 Sfântul Iustin Popovici, Omul şi Dumnezeul-om. Abisurile, şi culmile filosofiei, studiu introductiv şi traducere de Pr. prof. Ioan Ică şi Diac. Ioan I. Ică jr., Prefaţă de pr. Prof. Ioannis N. Karmiris, Postfaţă de Panayotis Nellas, Tipărită cu binecuvântarea Preasfinţitului Părinte Galaction, Arhiepiscopul Alexandriei şi Teleormanului, Bucureşti, Edit. Sophia-Editura Cartea Ortodoxă, 2010 , p. 32.

${ }^{37}$ Vezi Monica Cuciureanu, Simona Velea (coord.), Educația moral-religioasă în sistemul de educație din România, București, Edit. Didactică și Pedagogică, 2012.

${ }^{38}$ Dorin Opriș, Monica Opriș (coord.), Religia și Școala. Cercetări pedagogice, studii, analize, București, Edit. Didactică și Pedagogică, 2011, capitolele IV-X. 
vorbind, asociațiile și persoanele care militează pentru modificarea orei de religie din şcolile publice încearcă să schimbe un fond național și o tradiţie seculară, oferind în schimb principii ale unei etici de tip secular a cărei finalitate se rezumă doar la o minimă responsabilitate civică. În acest fel, se ignoră dezvoltarea armonioasă a spiritului uman susținut prin crezul său metafizic care dă valoare actelor sale și prin care se responsabilizează de efectul lor. Privarea moralei de religie conduce spre eliminarea ei din comportamentul uman. Etica ,înfățișează moralitatea ca provenind din puterea naturală a omului”, pe când morala religioasă ,deși recunoaște puterea naturală a omului, înfățișează moralitatea lui în primul rând ca energie a harului dumnezeieasc" 39 .

Educaţia religioasă/religios-morală presupune mult mai multe aspecte decât ceea ce se poate arăta prin enunțarea unor principii ale eticii. Religia și morala, în creștinism în special, sunt într-un raport inseparabil. Deși sunt două realități deosebite, avâns fiecare un specific propriu, ,,sunt realități distincte și nu sunt identice (...) și stau într-un raport special, ce nu e nici de coordonare, nici de subordonare, (...) ci amândouă se implică, se condiționează și se influențează reciproc" ${ }^{\prime 4}$. În ecuația paideică trebuie păstrată valența religioasă din care emană volens nolens principiile morale pe care tânărul și le asumă în funcție de propria personalitate. Chiar și pentru demersurile pedagogice actuale, raportul dintre religie și morală rămâne esențial ${ }^{41}$ în modelarea unui caracter uman și pentru înțelegerea și asumarea unor principii morale indispensabile. Față de etica filosofică (seculară) care proceadează empiric și analitic, morala religioasă creștină procedează sistemaetic și sintetic ${ }^{42}$. Între cele două componente, religie și morală, nu se poate crea un hiatus, în ceea ce privește integrarea lor în educație. Chiar dacă se oferă drept surogat al celor două elemente un autoreflex autonom al

\footnotetext{
${ }^{39}$ Sfântul Nectarie de Eghina, op. cit., p. 108.

${ }^{40}$ George Remete, Dogmatica ortodoxă, Alba Iulia, Edit. Reîntregirea, 2000, p. 43.

${ }^{41}$ Dorin Opriș, Dimensiuni creștine ale pedagogiei moderne, Ediția a III-a, București, Edit. Didactică și Pedagogică, 2012, pp. 25-28.

42 Sfântul Nectarie de Eghina, op. cit., p. 109.
} 
moralei/eticii cu ea însăși ca religie, totuși nu se poate justifica până la capăt demersul, făcând apel la structura ontologică a persoanei. Morala religiei râmâne însă absolută și imuabilă ${ }^{43}$ deoarece ea emană de al Autoritatea supremă, adică de la Dumnezeu.

${ }^{43}$ George Remete, op. cit., p. 44, 